Western University Scholarship@Western

Political Economy Research Group. Papers in

Political Economy

Economics Working Papers Archive

1998

\title{
Information, Civil Liberties, and the Political Economy of Witch-hunts
}

Vai-Lam Mui

Follow this and additional works at: https://ir.lib.uwo.ca/economicsperg_ppe

Part of the Economics Commons

Citation of this paper:

Mui, Vai-Lam. "Information, Civil Liberties, and the Political Economy of Witch-hunts." Political Economy Research Group. Papers in Political Economy, 90. London, ON: Department of Economics, University of Western Ontario (1998). 
POLITICAL

ECONOMY

RESEARCH

GROU

\title{
PAPERS IN POLITICAL ECONOMY
}

\section{Paper No. 90}

"Information, Civil Liberties, and the Political Economy of Witch-hunts"

\author{
Vai-Lam Mui
}

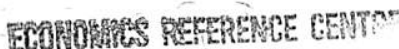

\section{0}

WRVERSTY OE WESTER OH...... 
The Political Economy Research Group was established in the Faculty of Social Science at the University of Western Ontario in 1988. Its purposè is to foster scholarship, teaching and interdisciplinary research in political economy, with à focus on:

1. the application of economic models and methods to the study of political processes and institutions,

2. the economic impact of political processes and institutions,

3. the influence of economic factors on the formation of public policy and on institutional change,

4. the politics of economic policy making, and

5. the political, social, and economic effects of public policy.

Co-directors:

Ronald Wintrobe (Economics)

Robert Young (Political Science)

Board of Directors:

Peter Howitt (Economics)

Michael-Keating (Political Science).

John N. McDougall (Political Science)

Peter Neary (History)

John Whalley (Economics)

\section{Staff:}

Yvonne Adams

For further information:

Political Economy Research Group,

Department of Economics,

Social Science Centre,

London, Ontario, Canada N6A 5C2

phone: (519) 661-2111, ext. 85231

fax: (519) 661-3666. 


\title{
Information, Civil Liberties, and the Political Economy of Witch-hunts
}

\author{
Vai-Lam Mui \\ Department of Economics \\ University of Southem California \\ Los Angeles, CA 90089-0253 \\ E-mail Address: vailam@almaak.usc.edu
}

August 1998

\begin{abstract}
Drawing from an extensive literature on the European Witch-Hunt, McCarthyism, and the Chinese Cultural Revolution, this paper studies how differences in the level of civil liberties protection and the extent to which the leader has better information about the level of the alleged menace than the populace, together with other variables, jointly determine the incidence of witchhunts. I develop a model showing that at any level of civil liberties protection, the incidence of illegitimate witch-hunts is higher when the leader enjoys an informational advantage than when he does not. This difference, however, is decreasing in the level of civil liberties protection. However, no amount of civil liberties protection is sufficient to prevent the occurrence of illegitimate witch-hunts, so long as the citizen has a concern for the menace, and the leader enjoys an informational advantage and finds the benefit from conducting a witch-hunt to be larger than his reputational loss.
\end{abstract}

Key Words: Witch-hunts, Information Asymmetry, Civil Liberties, Countervailing Action, Political Economy, Institutions

JEL Classifications: B49, D78, D82, K49, Z00 


\section{Introduction}

This paper studies how differences in political and legal institutions affect the incidence of purges like the European Witch-Hunt, McCarthyism, and the Chinese Cultural Revolution. Massive purges such as these cause great human suffering, and have significant detrimental impacts on the functioning of societies. During the European Witch-hunt, tens of thousands of people were executed as witches (Levack, 1995; Briggs, 1996). There is plausible evidence that at least half a million people died as a direct result of the Cultural Revolution (Harding, 1993). During the McCarthy era; the purges of "hidden Communists" in the State Department made it extremely costly for anyone in the Department to discuss possible benefits from initiating contact with Communist China (Rovere, 1959). People often conform to prevailing opinion to avoid being accused during purges. This prevents people from voicing opinions that may be useful for society to hear, and can preclude the consideration of appropriate courses of action. Since "witch-hunts" can impose great costs on society, it is important that we better understand the mechanisms through which differences in institutions affect their incidence. This is necessary if we are to design institutions or foster civic traditions to prevent tragic purges.

Many scholars and commentators have suggested that there are similarities between purges like the Anti-Communist purge, the Chinese Cultural Revolution, and the European Witchhunts (e.g.; Yue and Wakeman, 1985; Oplinger, 1990; Levack, 1995). There has not been, however, much effort to identify their common dimensions, and to develop an analytical framework to clarify the mechanisms that determine their incidence. ${ }^{1}$ This paper is an exploration in this direction, focusing on the role of institutional differences. I first present historical evidence to show that despite their many differences, several aspects are common to these three purges. First, genuine concems about a threat--witches, the "Red Menace", counter-revolutionaries--existed in these societies prior to and during the purges. Second, when certain members of a society were skeptical about the legitimacy of a witch-hunt, they resisted it. Third, the involvement of political leaders was crucial for the occurrences of these purges. Fourth, information asymmetries between 
political leaders and the populace were important in shaping their interactions. Building on these observations, I develop a game-theoretic model to analyze how differences in the extent to which the leader enjoys an informational advantage over the citizen, and the level of civil liberties protection--which affects the citizen's expected cost of resistance--jointly determine the incidence of witch-hunts. In the model, the leader first observes whether the level of menace is high or low, and then decides whether to "launch a witch-hunt." The citizen does not observe the level of menace, and has to decide whether to resist the witch-hunt once it is launched.

When citizens had a genuine concem for the menace, whether they resisted a witch-hunt or not depended upon their beliefs concerning the level of menace and their cost of resistance. In the model, when a citizen believes that the menace is high, she will consider a witch-hunt to be "tolerable," although she recognizes that it can impose high costs on society and even on herself. On the other hand, when she believes that the menace is low, she regards the witch-hunt as "illegitimate." However, even if a citizen regards a witch-hunt as illegitimate, she may not have the incentives to resist it. As suggested by many historical examples, critics of a witch-hunt often suffer severely for publicly voicing their dissent. In the model, better civil liberties protection reduces the citizen's cost of resistance, and increases the probability that the citizen will resist a witchhunt when she thinks that there is a sufficiently high probability that it is illegitimate, which in turn reduces the leader's incentives to launch a witch-hunt.

Because of his informational advantage, if the leader claims that the menace is high, the citizen does not know whether this claim is based on better information, or whether the leader is exaggerating the menace to induce others to support what they would otherwise consider to be an illegitimate witch-hunt. Using the model, I first show that under either complete or incomplete information, an improvement in civil liberties protection always reduces the incidence of illegitimate witch-hunts. However, at any level of civil liberties protection, the incidence of illegitimate witch-hunts is higher when the leader enjoys an informational advantage than when such informational asymmetry is absent. This difference, however, is decreasing in the level of civil liberties protection because an improvement in civil liberties protection reduces the citizen's cost of resis- 
tance, and thus reduces the leader's ability to manipulate his informational advantage. Nevertheless, the model also shows that so long as the citizen has a concern for the menace, whenever the leader enjoys an informational advantage and finds the benefit from conducting a witch-hunt to be larger than his reputational loss, then, no matter how strong civil liberties protection is, there is always a possibility that an illegitimate witch-hunt will occur.

Furthermore, because the citizen must decide whether to resist a witch-hunt without knowing whether it is illegitimate or tolerable, stronger civil liberties protection reduces the leader's ability to succeed in launching an illegitimate witch-hunt, and can also cause the citizen to resist what she would otherwise regard as a tolerable witch-hunt and prevent it from happening. This further implies that when civil liberties protection is sufficiently strong, the presence of information asymmetry can cause a decrease in the incidence of tolerable witch-hunts that is larger than the increase in the incidence of illegitimate witch-hunts, so that the overall incidence of witch-hunts under incomplete information is lower than that under complete information.

The rest of this paper is organized as follows. Section 2 introduces a definition of witchhunts. Section 3 discusses some important common aspects of witch-hunts. Section 4 presents the model and its findings. Section 5 concludes by discussing the limitation of this analysis, and highlights some of the directions for future research.

\section{What is a Witch-hunt?}

The term "witch-hunt" has been used by scholars and commentators to describe many different phenomena. I am not interested in promoting any particular definition as the proper one. However, to make the phenomena I am focusing on clear, I offer the following working definition: A witch-hunt occurs if a community is conducting a purge against an alleged hidden conspiracy, where in the process the community violates its own generally-practiced legal procedures.

The European Witch-Hunt--which roughly spanned the 15 th to the 17 th centuries--illustrates how this definition captures important aspects of the purges studied here. While concerns about harmful witchcraft had been present long before the European Witch-Hunt, what was 
unique about the purges during this period was the emerging idea that witches were people who had entered into pacts with the Devil and conspired to overthrow the existing social order. By the late 15 th century, the notion that witchcraft was a deliberate, hidden, and well-organized threat to society was quite well-established (Midelfort 1992; Levack, 1995; Clark,1997). As the notion of "a pact with the Devil" assumed greater significance, it became common for the accused to be tortured and forced to name others who had attended "sabbats"--mass meetings in which witches presumably worshiped the Devil.

During the European Witch-Hunt, the threat of witchcraft was thought to be so severe that it was considered acceptable to employ legal procedures that would otherwise be deemed unacceptable by the standards of the time. For example, Carolina, the German imperial law code of 1532 , stipulated that no one could be tortured without proper cause, which required one eyewitness or the presence of circumstantial evidence. Such protections, however, were not upheld during the witch-trials in the following decades. Given that witches were mainly accused of entering into pacts with Devil (a crime for which verifiable evidence was extremely difficult to collect), rather than simply practicing harmful witchcraft (a crime which was comparatively easier to verify), the judges had come to regard torture as the legitimate, and, indeed, the only means to force the witches to confess their crimes. By the end of the 16th century, the regular use of torture was widely accepted in Germany (Klaits, 1985:140).

In the Anti-Communist Purge, the alleged hidden conspiracy was presumably organized by Communists. In the Cultural Revolution, the "enemies of the people" were counter-revolutionaries. During the Anti-Communist purges, when critics argued that dubious methods and procedures had been employed, supporters would argue that even if violations of the law occurred during the purges, the severity of the threat justified them. The American Legion, in its effort to support McCarthy, noted that "McCarthhy's blunderbuss, loaded with rock-salt, birdshot, and nuts and bolts... is almost bound to bring down several important Reds and spies even though a few comparatively innocent people may get some rock-salt in their hides" (Oshinsky, 1983:206). During the Cultural Revolution, many of the alleged counter-revolutionaries were prosecuted and tor- 
tured in a manner that completely violated existing laws, and some were executed without trial (Yan and Gao, 1986; Barnouin and Yu, 1992).

\section{Some Important Aspects of Witch-hunts}

Historians have shown that a genuine fear of witchcraft was prevalent during the European Witch-Hunt (Thomas, 1971; Clark, 1997). The fear of Communists was quite real in the 1940's and the 50's in the U. S. A 1950 Gallup Poll showed that most Americans expected to be at war with Russia in the near future, and some politicians endorsed the growing demand that Communists be hanged (Oshinsky, 1983). Prior to the Cultural Revolution, there was a growing perception among Chinese citizens that some officials were behaving in a way that was inconsistent with socialist ideals (Whyte, 1989; Harding, 1993). Starting from the early 60 's, the government put increasing emphasis on the "family background" of an applicant--whether one came from the family of a worker, peasant, capitalist, etc.-in making university admission and job assignment decisions. This policy benefitted the families of powerful Party members at the expense of those from "bad family backgrounds." The resentment this caused was partly responsible for Mao's success in mobilizing citizens against the "capitalist roaders" (Lee, 1978; Whyte, 1989).

While genuine concern about a menace existed in these witch-hunts, there is also plenty of evidence that when certain citizens became skeptical about the legitimacy of a witch-hunt, they resisted it. These citizens usually did not deny that there might be reasons to be concerned about the menace in question. However, they usually disagreed with those who pursued the purges about the potential severity of the menace, and believed that the purges adopted dubious procedures that could cause too many innocent people to suffer. For example, while the Jesuits played a major role in the prosecution in Bamberg and Würzburg--among the worst of the European witch-trials-it was one of their members at Würzburg, Friedrich von Spee, who wrote one of the most influential attacks on the methodology of witch-trials. In his Cautio Criminalis of 1631, he attacked the remorseless use of torture in the trials, and emphasized that accusations obtained in this way were totally unreliable (Briggs, 1996). Moreover, as students of the European Witch-Hunt have 
observed, in some cases, these countervailing actions were instrumental in reducing the intensities of witch-hunts, or even stopping them. In a famous witch-hunt in Sweden in 1668-76, less than 15 percent of those accused were put to death, with the total number of executions being around 200 , largely because there were dissenting voices (Briggs, 1996).

From the beginning of his campaign, the validity of McCarthy's accusations was attacked in the press. After his Wheeling speech, in which McCarthy proclaimed that he had the list of 205 members of the Communist Party working in the State Department, the Milwaukee Journal called him a liar and a bully (Reeves, 1982). When McCarthy made his initial charges, Senator Magaret Smith believed he was on to something disturbing and frightening, but eventually she grew skeptical. In her 1950 Declaration of Conscience speech in the Senate, she argued that "the Senate has been made a rendezvous for vilification, for selfish political gain at the sacrifice of individual reputations and national unity." She emphasized the importance of upholding the Constitution's protection of due legal procedure, asserted that "it is high time that we remembered that the Constitution, as amended, speaks not only of the freedom of speech but also of trial by jury instead of trial by accusation," and emphasized that the exercise of the right to criticize; the right to uphold unpopular beliefs; the right to protest; the right to independent thought "should not cost one single American citizen his reputation or his right to a livelihood" (Klingaman, 1996:436). Students of the Cultural Revolution have also documented many incidents of citizens resisting the purges (Yan and Gao, 1986; Barnouin and Yu, 1992).

I now discuss the third common aspect of witch-hunts, namely, the crucial role of political leaders. A political leader is a person who has significant de facto control of the judicial and political institutions in his/her community. I first consider the role of political leaders in the European Witch-Hunt. In an influential study, Thomas (1971) attempted to explain why witchcraft accusations arose in the first place. Following the line pioneered by Evans-Pritchard (1937), Thomas argued that in many witchcraft accusations, the accuser and the accused were members of a closely knit community. He further argued that because of social and economic changes, people began to consider it acceptable not to offer assistance to the poor. A person who failed to give to a 
poor neighbor, however, might still feel guilty, and would expect the neighbor to feel angry toward her. If the person then suffered some misfortune or illness, she would believe it to be caused by her angry neighbor's acts of witchcraft.

As Cohn (1975) and Hall (1985) have pointed out, however, while this line of research provides plausible explanations for the origins of some individual witchcraft accusations, they cannot explain why massive pursuits of witches occurred during this period. Cohn instead emphasizes the role of political elites. He argues that during this period, many of these elites--the bishops, magistrates, and lawyers--had accepted the notion that some people were engaged in a conspiracy against the Christian church. Many massive witch-hunts occurred because the political elites used them to identify and eliminate real or imagined opposition to their authority. As Cohn has emphasized, "left to themselves, peasants would never have created mass witch-hunts--these occurred when the authorities had become convinced of the reality of the sabbat and of nocturnal flights to the sabbat" (Cohn, 1975:252). Larner (1981) pursues a similar explanation in her study of witch-trials in Scotland, arguing that these purges reflected the attempt of an emerging civil state to expand its control and impose ideological conformity on its populace.

Work by scholars such as Cohn and Lamer has demonstrated quite convincingly that a satisfactory explanation of the European Witch-Hunt must take into account the role of political leaders. While scholars pursuing this line of research have often emphasized the role of political leaders in "manipulating" or "fueling" the purges to achieve their political or religious agendas, they do not maintain that all witch-hunts are initiated or imposed by the leaders. A reasonable interpretation of this literature would be that mobilization of the formal judicial and political establishment against the witches was necessary for the occurrences of massive purges.

Political leaders also played prominent roles in the Anti-Communist Purge and the Cultural Revolution. In 1938, Congress created the House Committee on Un-American Activities (HUAC) to investigate potential threats posed by Nazi and Communist sympathizers. Starting in the late 1940 's, the HUAC, together with the Senate Government Operations Committee under the heavy influence of McCarthy, became the major vehicles through which politicians were actively 
involved in the Anti-Communist purges (Goodman, 1964; Caute, 1978). During the Cultural Revolution, the Chinese Communist Party announced the establishment of The Central Cultural Revolution Small Group in May 1966, and instructed the whole Party to be on guard against the "representatives of the bourgeoisie" who had sneaked into the Party and the government. Soon after, the Party issued the Sixteen Point Decision on the Cultural Revolution, stating that the goal of the Cultural Revolution was to mobilize workers, peasants, soldiers, cadres, and intellectuals to "struggle against and overthrow those persons in authority who are taking the capitalist road" (Barnouin and Yu, 1992:72). Encouraged by the Party's urge to mobilize, students began to form Red Guard groups. Mao showed his support for the Red Guards by attending the first of a series of mass parades. Soon, Red Guards began to search people's homes and persecute "enemies of the people." In support of these purges, the People's Daily (the official Party newspaper) asserted that "none of the old parasites hidden in dark comers can escape the sharp eyes of the Red Guards who are pulling out the bloodsuckers, these enemies of the people one by one." (Barnouin and Yu, 1992:98).

This discussion reveals that political leaders' involvement in witch-hunts can take different forms. In the Cultural Revolution, the leaders took the lead in initiating the massive purges. The most intense phase of the Anti-Communist purges, referred to as McCarthyism, could be viewed as "launched" by McCarthy in his Wheeling speech. In some European witch-trials, however, the leaders did not initiate the accusations, which instead sprang up from interactions between the members of a community. However, these individual accusations sparked off a massive purge only after the authorities became involved and used their power to force the accused to name others who had signed the pact with the Devil. Although the leaders did not initiate the accusations, they nevertheless "fueled" the witch-hunt by supporting the use of the formal political and judicial apparatus to conduct a massive purge after the accusations sprang up. To emphasize the fact that a massive purge against hidden enemies cannot happen without the support, or at least the endorsement, of those who control the political and judicial machinery in the community, I refer to these different cases using the expression, "the leader launches a witch-hunt." 
Another common aspect of witch-hunts is that information asymmetries are crucial in shaping the strategic interactions between political leaders and citizens. A leader has access to information not easily available to the populace. Therefore, if the leader makes a claim that the menace is high, the citizen faces an informational problem. The citizen does not know whether the leader makes such a claim because he has access to information indicating that menace is in fact high, or whether he is exaggerating the menace to induce others to support what they would otherwise consider to be an "illegitimate" witch-hunt. During the European Witch-Hunt, political and religious leaders often asserted that the confessions by the accused witches revealed the existence of a conspiracy against the social order, and hence, further purges were necessary. When confronted with such claims, the citizens--especially those who were not familiar with the accused-found it difficult to determine whether to give such claims the benefit of the doubt. When the Chinese Communist Party proclaimed that "enemies of the people" had sneaked into the Party and that a massive purge was necessary, a citizen had to determine whether or not to believe the Party's claim, without knowing whether it was based on genuine information.

A classic example of this information problem during the Anti-Communist purge is from McCarthy's famous Wheeling speech, in which he proclaimed that "while I cannot take the time to name all the men in the State Department who have been named as active members of the Communist Party and members of a spy ring, I have here in my hand a list of 205--a list of names that were made known to the Secretary of State as being members of the Communist Party and who nevertheless are still working and shaping policy in the State Department." (Reeves, 1982:25). As Oshinsky (1983) observes, the specific nature of these allegations made it difficult for the public not to give them at least the benefit of the doubt.

\section{The Model}

Consider a game of incomplete information between the leader $P$ and a citizen $T$ as represented in Figure 1. Both $P$ and $T$ know that the level of menace can either be "high" or "low." That is, $m$ can be equal to $m_{h}$ or $m_{l}$, with $m_{h}>m_{l}$. T knows that by virtue of his position, $P$ has 
access to information that is not available to her. Therefore, $T$ believes that it is possible that $P$ may be better-informed about the menace in society. I model this possibility by simply assuming that $P$ knows the true value of $m$, while this piece of information remains unavailable to $T$. In the game tree, this is represented by the fact that nature moves first and chooses the level of menace, and the realized value of $m$ is observed by $P$ before he decides whether to launch (or fuel) a witch-hunt. If $P$ chooses not to launch (plays $N L$ ), the game is ended. If $P$ chooses to launch a witch-hunt (plays $L$ ), $T$ then decides whether to engage (play $E$ ) or not to engage (play $N E$ ) in countervailing actions to resist it. If she plays $E$, then with probability $p$, her countervailing actions can prevent the witch-hunt from taking place. The value of $p$ can vary substantially across societies. The more powerful the leader relative to the citizen, the less likely the citizen can succeed in resisting a witch-hunt even if she is willing to incur the cost of doing so. If $T$ plays $N E$, the witch-hunt will then take place with certainty.

Let $\rho$ denote $P$ and $T$ 's common prior belief that the level of menace is $m=m_{l}$, with $0<\rho<1$. I will follow the convention of referring to the leader as a different "type" when he possesses different private information. I will refer to the leader as a "high type" leader and a "low type" leader when he knows that $m=m_{h}$ and $m=m_{l}$, respectively.

Recall that citizens may, on the one hand, have a genuine concern about a menace, but on the other hand, when they believe that a witch-hunt is "illegitimate," they are sometimes willing to take actions to resist it. I assume that when a citizen believes the level of menace is $m$, she will suffer from a disutility equal to $-m f_{T}$, where the subscript $T$ refers to citizen and $f_{T}$ measures the extent to which $T$ is fearful of the menace. If no action is taken to reduce the threat posed by the witches, $T$ will get the status quo payoff of $-m f_{T}$. If a witch-hunt takes place, $T$ gets a payoff equal to $-c-(1-\delta) m f_{T}$. A witch-hunt can reduce the menace by a fraction $\delta$, but will impose an expected cost of $c$ on the citizen consisting of several components. First, a witch-hunt may disrupt the functioning of government and society, and create strong pressures for people to conform to prevailing opinions. These can in turn reduce the welfare of the citizen. Second, a citizen who is not a witch also knows that there is the chance that she herself may be wrongly accused. Finally, 
while a witch-hunt may succeed in purging the real witches, it will almost always cause innocent people to be purged. The citizen's conscience may be disturbed when seeing innocent people suffer. Such pain can be most intense when the accused are relatives or friends.

In deciding whether to resist a witch-hunt, $T$ compares her payoff without a hunt to that with a hunt. She will consider a witch-hunt as tolerable if and only if $-c-(1-\delta) m f_{T}>-m f_{T}$, which is equivalent to $m>m_{T}^{c}=\frac{c}{\delta f_{T}}$. Thus, $T$ will consider a witch-hunt tolerable when she believes that the menace is sufficiently severe so that she prefers the witch-hunt to take place despite the expected costs. Not surprisingly, $m_{T}^{c}$ is decreasing in $f_{T}$ and $\delta$ and increasing in $c$. This implies that the citizen will be more willing to tolerate a witch-hunt: (i) the stronger $T$ 's aversion to the menace (ii) the more effective she believes the witch-hunt will be in identifying "witches" and (iii) the lower the expected cost imposed on her by a witch-hunt. On the other hand, when $m \leq \frac{c}{\delta f_{T}}, T$ regards a witch-hunt as illegitimate because the menace is not sufficiently severe to justify its expected costs. The more likely $T$ thinks that a witch-hunt will cause dramatic disruption or innocent people to be accused, or the more she has a moral concern about innocent people being purged, the more likely she will consider it to be illegitimate. Since whether $T$ considers a witch-hunt to be illegitimate or not depends on whether $\delta m f_{T}-c$ is positive or negative, without loss of generality, I will normalize $T$ 's payoff so that if a witch-hunt does not take place, her payoff will be zero, and her payoff will be $\delta m f_{T}-c$ when a witch-hunt takes place.

When describing a witch-hunt as "tolerable," I mean to capture the idea that the witchhunt is considered to be tolerable by the citizen given her preference, and by no means should this be interpreted as indicating that I consider a particular witch-hunt to be morally "tolerable." I should also stress that the current formulation allows for a wide variety of preferences and beliefs. For example, if a citizen believes that the alleged threat and the associated accusation are completely unreal--that is, $m=0$--then a citizen who has a moral concern for the wrongly accused will regard the purges to be illegitimate. On the other hand, this formulation can also accommodate the case of a person who is prejudiced against a certain group of people and hence considers a purge against this group to be "tolerable," although such a position may be morally dubious. 
As pointed out earlier, critics of a witch-hunt often suffer severely for publicly voicing their dissent. Indeed, critics have often been attacked as witches themselves. During the Trier witch-trial, the Chief Judge judged the accused witches leniently because he was not convinced by their confessions obtained through torture. The Prince-Archbishop eventually had him arrested on grounds of being a witch. After being tortured, he "confessed" his crimes and was burnt to death (Levack, 1995). During the Anti-Communist Purge, the HUAC accused many of its critics as Communist sympathizers (Caute, 1978). The fact that critics of the purges could suffer severely in their careers or personal lives has also been well-documented (Caute, 1978; Fried, 1990; Klingaman, 1996). Similar tragedies of severe suffering by critics have been documented by students of the Cultural Revolution (Yan and Gao, 1986; Bamouin and Yu, 1992). I assume that when a citizen resists a witch-hunt, she incurs an expected cost of $d$. This cost consists of two componentsthe opportunity cost of time and resources devoted to countervailing actions, and the expected cost that the citizen will bear in the event that she herself is purged due to her resistance.

I assume that the leader gets a benefit equal to $\delta m f_{P}+b$ from conducting a witch-hunt, where $\delta m f_{p}$ and $b$ are his "genuine" and "instrumental" benefits, respectively. The term $\delta m f_{p}$ denotes that like the citizen, the leader may have a genuine concem about the menace. The term $b$ emphasizes that the leader may also have instrumental motivations for launching a witch-hunt. A witch-hunt may help him prevent the deterioration of political fortune (as Rovere (1959) and Oshinsky (1983) suggest was the case of McCarthy); or regain his political power and control of major policy decisions (as Yan and Gao (1986) and Dittmer (1987) emphasize as one of Mao's major motivations for launching the Cultural Revolution), or as a way to achieve tighter political control over the populace (as Cohn (1975) and Larner (1981) emphasize was the case in some European witch-hunts).

While there are benefits to a leader from conducting a witch-hunt, there are also costs. For example, when certain citizens believe that a leader has launched an illegitimate witch-hunt, they may withdraw his support for him. I refer to this loss as the leader's reputational cost of launching an illegitimate witch-hunt. ${ }^{2}$ In some circumstances, this reputational loss can be sufficiently large 
to cost the leader his career. This possibility is well-illustrated by the downfall of McCarthy. There are also many examples that show that some Chinese citizens became critical of Mao as the Cultural Revolution progressed (Yan and Gao, 1986). I assume that if a leader launches a witchhunt that is eventually regarded by citizens as illegitimate, he suffers a reputation loss denoted by $R$. The value of $R$ may vary substantially across societies, depending on the nature of the political system. A substantial decrease in credibility can cause a leader to be voted out of office in a democratic society. A "comparable" loss in the leader's credibility in a non-democratic society may not be sufficient to cost him his position. However, in such a society, citizens can still undertake unobservable actions--short of a costly revolt-- that make it difficult for the leader to implement his desired policies.

When a low type leader does not launch a witch-hunt, his payoff is $y_{a P}=0$ and $T$ 's payoff is $y_{a T}=0$. If he launches a witch-hunt and the citizen resists it, then a witch-hunt will only occur with probability $(1-p)$, and the players' payoffs are $y_{c P}=(1-p)\left(\delta m_{p} f_{P}+b\right)-R$ and $y_{c T}=(1-p)\left(\delta m_{1} f_{T}-c-d\right)$. If a low type leader launches a witch-hunt and the citizen does not resist it, the payoffs are $y_{d P}=\delta m_{P} f_{P}+b-R$ and $y_{d T}=\delta m_{1} f_{T}-c$.

When deciding whether to resist a witch-hunt, the citizen does not know whether or not the leader has a "legitimate" reason for launching it. However, eventually information will become available which will help the citizen to better know what information about the menace was originally available to the leader. Such information can be generated through leakage by other political players or the work of reporters or scholars. Moreover, if a witch-hunt does take place, the citizen can usually gather information about its legitimacy by observing the outcomes of the purges--for example, whether most of the people being purged appear innocent. Therefore, when the low type leader is contemplating whether to launch a witch-hunt, he takes into account that the citizen may eventually find out that he has launched an illegitimate witch-hunt, which will cause him a reputation loss. For simplicity, I assume that the citizen will eventually know perfectly whether or not the leader observed a high or low level of menace when choosing whether to launch a witch-hunt. My conclusions will not change so long as the information revealed to the 
citizen is rich enough so that a low type leader is sufficiently more likely to suffer a reputation loss than the high type leader for launching a witch-hunt.

When a high type leader does not launch a witch-hunt, his payoff is $y_{b P}=0$ and $T$ 's payoff is $y_{b T}=0$. If he launches a witch-hunt and $T$ resists it, the payoffs are $y_{e P}=(1-p)\left(\delta m_{h} f_{P}+b\right)$ and $y_{e T}=(1-p)\left(\delta m_{h} f_{T}-c-d\right)$. If a high type leader plays $L$ and $T$ plays $N E$, the payoffs are $y_{f P}=\delta m_{h} f_{P}+b$ and $y_{f T}=\delta m_{h} f_{T}-c$. Note that an high type leader does not suffer from any reputation loss when he launches a tolerable witch-hunt.

I also make the following assumptions to rule out less interesting cases in the model.

A 1. $\rho>\frac{\delta m_{h} f_{T}-c}{\delta\left(m_{h}-m_{l}\right) f_{T}}$.

A 2. $\delta m_{1} f_{P}+b \geq R$

A 3. $1-\frac{R}{\delta m_{1} f_{P}+b}<p$

Al says that $T$ 's prior belief is such that there is a sufficiently high probability that the menace is low. Therefore, when $T$ cannot gain any useful information regarding the true level of menace upon observing $P$ 's chosen action, $T$ will assign a sufficiently high probability that a witch-hunt is likely to be illegitimate. A2 says that when the menace is low, $P$ 's benefit from conducting a witch-hunt is larger than the reputational cost of launching an illegitimate hunt, so that $P$ will definitely launch a hunt if he is certain that $T$ will not resist it. A3 guarantees that the citizen's countervailing actions are sufficiently effective so that if the low type leader knows that $T$ will certainly resist the witch-hunt, the leader's expected benefits from a witch-hunt will not be sufficient to offset the reputation loss and he will not launch it. I will also assume that if the citizen is indifferent between resisting or not resisting a witch-hunt, she will not resist it. Moreover, if the leader is indifferent between launching or not launching a witch-hunt, she will launch it.

Recall that $T$ incurs an expected cost of $d$ for resisting a witch-hunt, where a major component of $d$ is the expected cost that she will bear if she herself is purged due to her resistance. As suggested by many historical examples, better protection of civil liberties reduces the expected 
cost a critic will suffer. Therefore, the stronger the protection of civil liberties, the less costly it is for a citizen to resist a witch-hunt. Thus, differences in the extent to which civil liberties are protected across different societies, or changes in such protection over time in a given society, will have an effect on the incidence of witch-hunts through their effects on the strategic interactions of the relevant parties.

For example, when there is a strong protection of the freedom of expression, a citizen knows that if she criticizes the legitimacy of the purges openly, or if she openly defends persons whom she considered to have been wrongly accused, it is less likely that others will be able to purge her for doing so. During the Anti-Communist Purge, many of its critics appealed to the Constitution to defend their right to express doubts about the purges (Caute, 1978; Oshinsky, 1983; Fried, 1990). In several HUAC hearings, witnesses' were able to invoke the First or the Fifth Amendment as a basis for refusing to answer questions. This led to highly-publicized legal battles between the government and the witnesses. Conversely, without effective protection against torture or other violations of due process, a citizen knows that if she is accused as a "witch" for resisting a witch-hunt, she is very likely to be convicted even if she is innocent. This fact has been emphasized by students of the European Witch-Hunt (Levack, 1995; Briggs, 1996) and the Cultural Revolution (Yan and Gao, 1986; Barnouin and Yu, 1992).

Finally, in societies that have enjoyed a long tradition of well-protected freedom of association, citizens have formed political, professional, and social organizations. The existence of these organizations makes it easier for citizens to organize countervailing actions against a witch-hunt, and to increase their effectiveness. During the Anti-Communist Purge, the HUAC employed many tactics to intimidate witness's lawyers. This led some lawyers to engage in formal litigation or informal campaigns against the HUAC to urge it to cease using such tactics, and their efforts received significant help from many civil and professional organizations. In 1953, the District of Columbia Bar Association recommended that a witness's counsel should have the right to object to questions and procedures in HUAC hearings. In 1957, the California State Bar Board of Governors strongly protested the HUAC's treatment of witnesses' attomeys (Caute, 1978). 
Let $l$ denote the level of civil liberties protection in society. To capture the idea that an improvement in civil liberties protection decreases the citizen's expected cost of resistance, I assume that $d(l)>0, d^{\prime}(l)<.0$. The solution concept I employ for this model is Perfect Bayesian Equilibrium. This concept embodies the idea that the citizen (the uninformed party) will try to infer the private information the leader possesses about the menace from the strategy adopted by the leader (the informed party). Anticipating this, the leader takes into account the fact that in equilibrium, his action may signal to the citizen what the level of menace is when he decides whether to launch a witch-hunt.

A (pure) strategy profile in this game is a triplet $\left(s_{p}^{h}, s_{p}^{l}, s_{t}\right)$, where $s_{p}^{h}, s_{P}^{l}$ and $s_{T}$ denote the strategy chosen by the high type leader, the low type leader, and the citizen, respectively. Let $\bar{\rho}$ denote $T$ 's posterior belief that $P$ is the low type--that is, $m=m_{l}$--upon observing that a witchhunt is being launched. In a separating equilibrium, the low type leader and the high type leader each chooses a different strategy, so that upon observing whether a witch-hunt is being launched, $T$ can infer precisely whether $P$ is of a low type or an high type. Therefore, $\bar{\rho}$ equals either zero or one. In a pooling equilibrium, both types of leader choose the same strategy so that the citizen cannot gain any new information upon observing the action taken by the leader and $\tilde{\rho}=\rho$. In such games of incomplete information, there is also the possibility of a hybrid equilibrium in which one type of leader plays a pure strategy of either $L$ or $N L$ while the other type randomizes between $L$ and $N L$. In this case, observing whether or not a witch-hunt is launched will help the citizen gain some, but imperfect, information about the type of the leader.

\subsection{Equilibrium under Complete Information}

As a benchmark for comparison, I first characterize the equilibrium of the game when the realized value of $m$ is observed by both $P$ and $T$. Suppose $m=m_{l}$ so that $T$ regards a witch-hunt as illegitimate: If $P$ launches a witch-hunt, $T$ will resist iff $y_{c T}>y_{d T}$, which is equivalent to $d<\frac{p}{1-p}\left(c-\delta m_{l} f_{T}\right)=\bar{d}$. That is, $T$ will resist when the cost of doing so is lower than the threshold value $\bar{d}$. Therefore, $P$ knows that when $d \geq \bar{d}$, if he launches a witch-hunt, he will not 
face any resistance and assumption A2 implies that $P$ will do so in this case. If $d<\bar{d}$, however, $P$ anticipates that if he launches a witch-hunt, $T$ will always resist it. Given that $P$ 's benefits from conducting the hunt are not too high compared to the costs (assumption A3), this threat is sufficient to deter him from launching the hunt. If $m=m_{h}$, regardless of the value of $d, T$ will not resist what she considers to be a "tolerable" witch-hunt and $P$ will always launch a witch-hunt.

The above discussion characterizes the equilibrium as a function of $d$. Since this cost is decreasing in $l$, the level of civil liberties protection, we can also describe the equilibrium as a function of $l$. Define $l$ and $i$ to be such that $d(l)=\frac{p}{1-p}\left(c-\delta m_{T} f_{T}\right)=\bar{d}$ and $d(i)=\frac{p}{1-p}\left\{c-\delta\left[\rho m_{l}+(1-\rho) m_{h}\right] f_{T}\right\}=\underline{d}$. I will hereafter refer to the case of $l \leq l$, $l<l \leq i$, and $l>i$ as weak, intermediate, and strong civil liberties protection, respectively.

Proposition 1. Suppose that the realized value of $m$ is observed by both $P$ and $T$ before they make any decisions. Then, under A2 and A3, we get: (i) If $m=m_{l}$, and civil liberties protection is weak $(l \leq l)$, this game has a unique equilibrium $(L, N E)$. If $m=m_{l}$ and civil liberties protection is intermediate or strong $(l>l)$, this game has a unique equilibrium $(N L, E)$. (ii) If $m=m_{h}$, this game has a unique equilibrium $(L, N E)$.

\subsection{Equilibrium under Incomplete Information}

Now consider the case when there is incomplete information. Let $\tilde{\rho}$ denote $T$ 's posterior belief that the menace is low upon observing that a witch-hunt is launched. Given $\tilde{\rho}, T$ will prefer $E$ to $N E$ iff $\tilde{\rho} y_{c T}+(1-\tilde{\rho}) y_{e T}>\bar{\rho} y_{d T}+(1-\tilde{\rho}) y_{f T}$, where the L.H.S. is her expected payoff from resisting a witch-hunt, while the R.H.S. is her payoff when not resisting. This implies that $T$ will resist iff $d$ is less than the threshold value $\tilde{d}(\bar{\rho})=\frac{p}{1-p}\left\{c-\delta\left[\tilde{\rho} m_{l}+(1-\tilde{\rho}) m_{h}\right] f_{T}\right\}$ (the notation $\tilde{d}(\tilde{\rho})$ emphasizes the fact that this value now depends on $\bar{\rho}$ ). Applying this observation to the case of $\tilde{\rho}=0, \tilde{\rho}=\rho$, and $\bar{\rho}=1$ respectively, I get

Lemma 1. (i) If $\bar{p}=0$, then for any value of $d, T$ 's dominant strategy is $N E$. (ii) Sup- 
pose $\bar{\rho}=\rho$. If $d<\underline{d}, T$ 's best response is $E$, otherwise, her best response is $N E$. (iii) Suppose $\bar{\rho}=1$. If $d<\bar{d}, T$ 's best response is $E$, otherwise, her best response is $N E$.

When $\tilde{\rho}=0$, the citizen believes that the level of menace is high upon observing that a witch-hunt is launched. Therefore, $T$ considers a witch-hunt to be tolerable and will not resist it regardless of the level of civil liberties protection. The case of $\tilde{\rho}=\rho$ corresponds to the situation where $T$ cannot obtain any useful information about the level of menace upon observing that a witch-hunt is launched so that her posterior belief is identical to her prior belief. This will occur in a pooling equilibrium in which both types of leader launch a witch-hunt with certainty. Recall that $\rho>\frac{\delta m_{h} f_{T}-c}{\delta\left(m_{h}-m_{l}\right) f_{T}}$ (assumption A1), that is, $T$ 's prior belief is such that there is a sufficiently high probability that the menace is low. Therefore, when $\tilde{\rho}=\rho, T$ will prefer that a witch-hunt not take place, but she will resist it if and only if $d$-the cost of resistance--is lower than the threshold value $\bar{d}(\rho)=\frac{p}{1-p}\left\{c-\delta\left[\rho m_{l}+(1-\rho) m_{h}\right] f_{T}\right\}=\underline{d}$. When $\bar{\rho}=1, T$ believes that the menace is low and regards a witch-hunt as illegitimate, and she will resist the witch-hunt iff $d<\tilde{d}(1)=\frac{p}{1-p}\left(c-\delta m_{P} f_{T}\right)=\bar{d}$.

This discussion shows that except for the special case of $\tilde{\rho}=1, \tilde{d}(\tilde{\rho})$ will differ from the "corresponding" threshold value $\bar{d}=\frac{p}{1-p}\left(c-\delta m_{P} f_{T}\right)$ under complete information. The citizen's best response function under incomplete information will therefore differ from that under complete information. Moreover, since $\tilde{d}(\rho)=\underline{d}$ and $\bar{d}(1)=\bar{d}, \tilde{d}(\rho)<\bar{d}(1)$. This implies that when $\underline{d} \leq d<\bar{d}, T$ will resist a witch-hunt when she knows for certain that the menace is low under complete information $(\tilde{\rho}=1)$, but will not do so when she remains uninformed about the level of menace in a pooling equilibrium under incomplete information $(\tilde{\rho}=\rho)$. That is, the presence of information asymmetry weakens the citizen's incentives to resist a witch-hunt.

Proposition 2. Under A1-A3, this game does not have any separating equilibrium.

Proof: First, observe that if the high type leader plays $L$, the lowest payoff he can get is $(1-p)\left(\delta m_{h} f_{P}+b\right)$--the expected payoff he gets when $T$ resists the hunt. If he plays $N L$, he will get a zero payoff. Therefore, the high type leader will always play $L$. Thus, if a separating 
equilibrium exists, it must be either $(L, N L, E)$ or $(L, N L, N E)$. In both cases, $T$ will infer that $P$ is the high type when a witch-hunt is launched. However, by lemma 1 , when $\tilde{\rho}=0, T$ will play $N E$ since she will not resist what she considers a tolerable witch-hunt. Therefore, if a separating equilibrium exists, it must be $(L, N L, N E)$. However, $(L, N L, N E)$ cannot be an equilibrium. By playing $N L$, the low type leader gets a zero payoff. Given $T$ 's belief, if the low type leader deviates and plays $L$--that is, if he "imitates" the strategy of the high type leader-- $T$ will infer that he is a high type and therefore will play $N E$. By deviating to $L$, the low type leader gets a payoff $y_{d P}=\delta m_{P} f_{P}+b-R>0$. The low type leader thus has an incentive to deviate and $(L, N L, N E)$ cannot be an equilibrium. Q.E.D.

Thus, regardless of the value of $d$, no separating equilibrium exists. It tums out that, depending on the value of $d$, this game either has a pooling equilibrium or a hybrid equilibrium. Consider first the case of $d<\underline{d}$, which corresponds to the case of strong civil liberties protection $(l>i)$. From the proof of proposition 1, we know that the high type leader always chooses $L$. Hence, if a pooling equilibrium exists, it must be that both types of leaders play $L$. In this case, $T$ 's posterior belief is $\bar{\rho}=\rho$, and she will resist a witch-hunt iff $d<\tilde{d}(\rho)=\underline{d}$. Since $d$ is now lower than $\underline{d}$, even if $\tilde{\rho}=\rho$-that is, even if $T$ cannot obtain any useful information from observing $P$ 's chosen action- $T$ will always resist a witch-hunt. Therefore, if a pooling equilibrium exists, it must be $(L, L, E)$. However, given that $T$ plays $E$, the low type leader will prefer $N L$ to $L$. Hence, $(L, L, E)$ cannot be an equilibrium. Given that the leader's expected benefit from conducting an illegitimate witch-hunt is not too large relative to his reputation loss (assumption A3), the credible threat that an uninformed citizen will always resist a hunt is sufficient to deter the leader from launching a witch-hunt. Therefore, a pooling equilibrium does not exist in this case.

This leaves the possibility of a hybrid equilibrium. Suppose that such an equilibrium exists and is denoted by $\left(L, \alpha^{*}, \beta^{*}\right)$, where $\alpha^{*}$ is the probability that the low type leader will play $L$ and $\beta^{*}$ is the probability that the citizen will play $E$. In this case, $T$ 's posterior belief will be $\tilde{\rho}=\frac{\rho \alpha^{*}}{\rho \alpha^{*}+(1-\rho)} \cdot{ }^{3}$ If such an equilibrium exists, it must be that given $\tilde{\rho}$ and the strategies of both types of leader, $T$ is indifferent between $E$ and $N E$ and therefore is willing to randomize. 
This requires that $\bar{\rho} y_{c T}+(1-\bar{\rho}) y_{e T}=\bar{\rho} y_{d T}+(1-\tilde{\rho}) y_{f T}$. Solving for $\alpha^{*}$, I get

$$
\alpha^{*}=\frac{1-\rho}{\rho} \frac{(1-p) d-p\left(c-\delta m_{h} f_{T}\right)}{p\left(c-\delta m_{1} f_{T}\right)-(1-p) d} \text {. It is easy to show that when } d<\underline{d}, 0<\alpha^{*}<1 \text {. }
$$

Similarly, if a hybrid equilibrium exists, it must be the case that given $\beta^{*}$, a low type leader is indifferent between $L$ and $N L$ and therefore is willing to randomize. This requires that $\beta^{*} y_{c P}+\left(1-\beta^{*}\right) y_{d P}=0$, which implies that $\beta^{*}=\frac{1}{p}\left(1-\frac{R}{\delta m_{1} f_{P}+b}\right)$. Assumption A2 ensures that $\beta^{*}>0$ while assumption $A 3$ ensures that $\beta^{*}<1$. By construction, $\left(L, \alpha^{*}, \beta^{*}\right)$ is a Perfect Bayesian Equilibrium.

Now consider the cases of $\underline{d} \leq d<\bar{d}$ and $d \geq \bar{d}$, which correspond to the cases of intermediate and weak civil liberties protection, that is, $l<l \leq i$ and $l \leq l$, respectively. It turns out that this game has a unique pooling equilibrium $(L, L, N E)$ whenever $l \leq i$. As in the case of $d<\underline{d}$, since the high type leader always chooses $L$, if a pooling equilibrium exists, it must involve both types of leader playing $L$. Therefore, $\bar{\rho}=\rho$. As pointed out above, when $\bar{\rho}=\rho, \bar{d}(\rho)=\underline{d}$. That is, when $T$ has a posterior belief $\tilde{\rho}=\rho$, she will resist a witch-hunt if and only if $d<\underline{d}$. Given that we now have $d \geq \underline{d}$ instead of $d<\underline{d}, T$ 's best response is $N E$ when a witch-hunt is launched. Therefore, if a pooling equilibrium exists, it must be $(L, L, N E)$. To establish that $(L, L, N E)$ is in fact an equilibrium, note that by playing $L$, the low type leader gets a payoff $y_{d P}=\delta m_{P} f_{P}+b-R>0$. Therefore, he has no incentive to deviate. Finally, it is easy to show that an hybrid equilibrium does not exist in this case. In summary,

Proposition 3. Under A1-A3, when $l \leq i$, this game has a unique pooling equilibrium $(L, L, N E)$. When $l>i$, this game has a unique hybrid equilibrium $\left(L, \alpha^{*}, \beta^{*}\right)$.

\subsection{Information, Civil Liberties, and the Equilibrium Incidence of}

\section{Witch-hunts}

In this section, I discuss how differences in civil liberties protection and the extent to which the leader enjoys an informational advantage jointly determine the incidence of witchhunts. As the first step to this exercise, I first analyze how changes in $l$ affect the incidence of ille- 
gitimate witch-hunts in the presence of information asymmetry.

Consider first how an increase in $l$ affects $\alpha^{*}$--the probability that the low type leader will launch a witch-hunt when there is strong civil liberties protection. Recall that when the citizen has a posterior belief $\tilde{\rho}$, she will resist the witch-hunt when $d<\tilde{d}(\tilde{\rho})$. As pointed out earlier, when $\tilde{\rho}=\rho, \tilde{d}(\rho)=\underline{d}$. Since we now have $l>\bar{l}$, and equivalently, $d<\underline{d}$, even if $T$ 's posterior belief is $\tilde{\rho}=\rho, T$ will always resist a witch-hunt, which will be sufficient to deter the low type leader from playing $L$. Therefore, when $l>i$, in order to succeed in launching a witch-hunt, the low type leader must choose a strategy that will induce a posterior belief $\tilde{\rho}<\rho$. This condition is satisfied under the equilibrium $\left(L, \alpha^{*}, \beta^{*}\right)$. In this case, the low type leader plays $L$ with a probability smaller than that played by the high type leader, so that upon observing that a witch-hunt is being launched, $T$ will adjust her belief that $P$ is a low type "downward" from $\rho$ to $\tilde{\rho}=\frac{\rho \alpha^{*}}{\rho \alpha^{*}+(1-\rho)}<\rho$. Moreover, since $d$ is decreasing in $l$, when $l$ increases, to ensure that $T$ is willing to randomize between $E$ and $N E$, the low type leader will need to choose an even smaller probability of playing $L$ so as to induce an "appropriate" decrease in $\bar{\rho}$. ${ }^{4}$ This suggests that $\alpha^{*}$ should be decreasing in $l$, which is confirmed by the fact that $\frac{\partial \alpha^{*}}{\partial d}=\frac{1-\rho}{\rho} \frac{(1-p) p \delta\left(m_{h}-m_{l}\right) f_{T}}{\left[p\left(c-\delta m f_{T}\right)-(1-p) d\right]^{2}}>0$, which in turn implies that $\frac{\partial \alpha^{*}}{\partial l}=\frac{\partial \alpha^{*}}{\partial d} \frac{\partial d}{\partial l}<0$.

Let $\gamma^{*}$ denote the probability that an illegitimate witch-hunt takes place in equilibrium. To calculate $\gamma^{*}$, recall that when $l>i$, the equilibrium is $\left(L, \alpha^{*}, \beta^{*}\right)$, and an illegitimate witch-hunt will take place if and only if all of the following events happen. First, $m=m_{l}$, which occurs with probability $\rho$. Second, the low type leader plays $L$, which happens with probability $\alpha^{*}$. Third, either the citizen plays $N E$--this occurs with probability $\left(1-\beta^{*}\right)$; or she plays $E$ but her resistance fails to prevent the witch-hunt from taking place--this event occurs with probability $\beta^{*}(1-p)$. Therefore, when $l>i, \gamma^{*}=\rho \alpha^{*}\left[\left(1-\beta^{*}\right)+\beta^{*}(1-p)\right]=\rho \alpha^{*}\left(1-\beta^{*} p\right)$. Furthermore, when $l \leq i$, the equilibrium is $(L, L, N E)$, which implies that $\gamma^{*}=\rho$. Since $\gamma^{*}=\rho$ when $l \leq i$, so long as there is only weak or intermediate civil liberties protection, an increase in $l$ has no effect on $\gamma^{*}$. However, when $l>i, \frac{d \gamma^{*}}{d l}=\rho\left(1-\beta^{*} p\right) \frac{\partial \alpha^{*}}{\partial l}<0$, Therefore, we conclude 
that an increase in civil liberties protection reduces the incidence of illegitimate witch-hunt when the leader enjoys an informational advantage over the citizen.

Table 1.summarizes how.differences in civil liberties protection and the extent to which the leader enjoys an informational advantage jointly determine the equilibrium strategies of the leader and the citizen, as well as the incidence of witch-hunts. An examination of rows 1 and 2 reveals that an improvement in civil liberties protection always reduces the leader's incentives to launch an illegitimate witch-hunt under either complete or incomplete information. A comparison of each cell in row 1 to the cell directly below it in row 2 also reveals that the probability that the low type leader will launch a witch-hunt under incomplete information is always higher than or equal to that under complete information. This difference, however, is decreasing in the level of civil liberties protection because $\alpha^{*}$ is less than one and declining in $l$.

The intuition for this difference is as follows. With weak civil liberties protection, the citizen expects that she will pay a high cost for resisting a witch-hunt, which is sufficient to deter her from doing so even when she knows for certain that the witch-hunt is illegitimate. The low type leader will therefore launch a hunt with certainty under complete information because he anticipates that he will not face any resistance. Under incomplete information, the game has a pooling equilibrium $(L, L, N E)$ and $T$ 's posterior belief is $\tilde{\rho}=\rho$ so that she prefers that a witch-hunt not take place. However, with weak civil liberties protection, $T$ will not resist the witch-hunt even when she knows for certain that the menace is low. Therefore, she will be even more reluctant to do so when she believes that there is actually a positive probability that the menace is high--that is, the fact that $\bar{\rho}=\rho$ further weakens her incentives to resist. Anticipating that there will be no resistance, the low type leader will again launch a witch-hunt.

Now consider what happens when $l$ increases from a weak to an intermediate level--that is, from some $l \leq l$ to $l<l \leq i$. As shown in Table 1 , under complete information, such an increase in $l$ is sufficient to guarantee that if a low type leader launches a witch-hunt, he will face resistance. On the contrary, under incomplete information, such an increase in $l$ is now insufficient to induce the citizen to engage in countervailing actions. Since $\bar{\rho}=\rho$ in the pooling equilibrium 
$(L, L, N E), T$ will voluntarily refrain from resisting a witch-hunt. In equilibrium, the benefit of a decrease in the cost of resistance conferred on the citizen by an improvement of civil liberties protection from a weak to an intermediate level is completely offset by the leader's informational advantage over the citizen. By exploiting this informational advantage, the leader can still succeed in launching an illegitimate witch-hunt even when there is intermediate civil liberties protection.

When there is strong civil liberties protection, under complete information, the low type leader does not launch a hunt because he expects that it will be resisted. As explained earlier, however, even when $l>i$, under incomplete information, the leader can still exploit his informational advantage to launch an illegitimate witch-hunt. In equilibrium, the low type leader launches a witch-hunt with a probability $0<\alpha^{*}<1$, and $T$ resists it with a probability $0<\beta^{*}<1$.

This comparison between rows 1 and 2 in Table 1 establishes that the low type leader always launches a witch-hunt with a higher probability under incomplete information than under complete information. This difference equals one under intermediate civil liberties protection, but decreases to $\alpha^{*}<1$ under strong civil liberties protection. Moreover, this difference is further declining in $l$ whenever $l>i$ since $\frac{\partial \alpha^{*}}{\partial l}<0$. While the low type leader will launch an illegitimate witch-hunt with a higher probability under incomplete information, an improvement in civil liberties protection reduces the leader's ability to exploit the informational advantage in his interest.

As a corollary to the above results, a comparison of each cell in row 3 to the cell directly below it in row 4 shows that except for the case of $l<l$ (where $\gamma^{*}=\rho$ under either complete or incomplete information), the incidence of illegitimate witch-hunts is always higher under incomplete information than under complete information, but this difference is decreasing in $l$. In particular, the fact that $\alpha^{*}$ is decreasing in $l$, together with the fact that the citizen will resist the witch-hunt with a positive probability when $l>i$, imply that the difference between the incidence of illegitimate witch-hunts under incomplete information vis-a-vis complete information decreases when moving from intermediate to strong civil liberties protection.

Recall that the citizen has a genuine concern for the menace, and will prefer a witch-hunt to take place if she believes that there is a sufficiently high probability that the menace is high. 
This implies that even if it is costless for the citizen to resist a witch-hunt, if the citizen believes that there is a sufficiently high probability that the menace is high--that is, if her posterior belief $\tilde{\rho}$ is sufficiently.small--she will not.resist a witch-hunt. Stronger civil liberties protection reduces the leader's ability to manipulate his informational advantage and therefore reduces the incidence of illegitimate witch-hunts. However, so long as the citizen has a concern for the alleged menace, no amount of civil liberties protection is sufficient to prevent the occurrence of illegitimate witchhunts whenever the leader enjoys an informational advantage. This is because when the leader finds the benefit from conducting a witch-hunt to be larger than the reputational loss, he can manipulate his informational advantage to ensure that the citizen gives him the benefit of the doubt about the level of the menace and succeed in launching an illegitimate witch-hunt, even if civil liberties protection is so strong that $d$--the citizen's cost of resistance, can be regarded as zero.

To see this formally, observe that when $d=0, \alpha^{*}=\frac{(1-\rho)}{\rho} \frac{\left(\delta m_{h} f_{T}-c\right)}{\left(c-\delta m_{1} f_{T}\right)}>0$, and an illegitimate witch-hunt will still occur with a positive probability $\gamma^{*}=(1-\rho) \frac{\left(\delta m_{h} f_{T}-c\right)}{\left(c-\delta m_{1} f_{T}\right)}\left(1-\beta^{*} p\right)>0$. Even when $d=0$, by playing $L$ with a probability that is smaller than that played by the high type leader (in particular, by choosing $\left.\alpha^{*}=\frac{(1-\rho)}{\rho} \frac{\left(\delta m_{h} f_{T}-c\right)}{\left(c-\delta m_{f}\right)}<1\right)$, the low type leader can ensure that $T$ will have a posterior belief $\vec{\rho}$ that is sufficiently smaller than her prior belief $\rho$, so that the citizen will refrain from resisting a witch-hunt with a positive probability, and an illegitimate witch-hunt will still take place with a positive probability.

Another interesting implication of the model is that while stronger civil liberties protection reduces the incidence of illegitimate witch-hunts, it also reduces the incidence of what the citizen herself would regard as "tolerable" witch-hunts. An examination of row 6 in Table 1 indicates that an improvement in civil liberties protection reduces the incidence of tolerable witch-hunts under incomplete information. In particular, when there is strong civil liberties protection, even if the level of menace is in fact high, a tolerable witch-hunt may not occur. On the other hand, row 5 in Table 1 shows that under complete information, an increase in civil liberties protection has no 
effect on the incidence of tolerable witch-hunts because the citizen will not resist a witch-hunt when he knows for certain that the menace is high.

The intuition of these results is as follows. An increase in $l$, by reducing $d$, reduces the leader's ability to succeed in launching an illegitimate witch-hunt under either complete or incomplete information. However, under incomplete information, an improvement in civil liberties protection--by reducing the citizen's cost of resistance--can also cause the citizen to resist what she would otherwise regard as a tolerable witch-hunt and prevent it from happening. Therefore, as revealed by an examination of rows 7 and 8 in Table 1 , an improvement in civil liberties protection reduces the overall incidence of witch-hunts (the sum of the incidence of both types of witchhunt) under either complete or incomplete information.

Proposition 4. Suppose that A1-A3 hold. Then under either complete or incomplete information, an improvement in civil liberties protection always reduces the equilibrium incidence of illegitimate witch-hunts. However, for any level of civil liberties protection, the incidence of illegitimate witch-hunts is higher under incomplete information than that under complete information. This difference, however, is decreasing in the level of civil liberties protection. Furthermore, so long as the citizen has a concern for the alleged menace, whenever the leader enjoys an informational advantage and finds the benefit from conducting a witch-hunt to be larger than the reputational loss, no amount of civil liberties protection is sufficient to prevent the occurrence of illegitimate witch-hunts. Moreover, while stronger civil liberties protection reduces the incidence of illegitimate witch-hunts under either complete or incomplete information, it also reduces the incidence of "tolerable" witch-hunts under incomplete information. Thus, under either complete or incomplete information, an improvement in civil liberties protection reduces the overall incidence of witch-hunts.

As pointed out above, at any level of civil liberties protection, the presence of informational asymmetry always increases the incidence of illegitimate witch-hunts. However, a comparison of each cell in row 5 to the cell directly below it in row 6 also reveals when there is strong 
civil liberties protection, the presence of informational asymmetry reduces the incidence of tolerable witch-hunts. Therefore, it is natural to ask whether there exist conditions under which the decrease in the incidence of tolerable witch-hunts caused by the presence of informational asymmetry is larger than the corresponding increase in illegitimate witch-hunts, so that the overall incidence of witch-hunts under incomplete information could actually be lower than that under complete information. ${ }^{5}$ To see how the presence of informational asymmetry affects the overall incidence of witch-hunts under different level of civil liberties protection, compare each cell in row 7 to the cell directly below it in row 8 . When there is weak civil liberties protection, informational asymmetry has no effect on the overall incidence of witch-hunts. In this case, the leader can succeed in launching an illegitimate witch-hunt even under complete information. Thus, the presence of informational asymmetry does not give the leader any additional strategic advantage, and therefore has no effect on the incidence of illegitimate witch-hunts, and similarly no effect on the incidence of tolerable witch-hunts. Under intermediate civil liberties protection, the leader's informational advantage increases the incidence of illegitimate witch-hunts, but has no effect on the incidence of tolerable witch-hunts. Therefore, in this case, the overall incidence of witch-hunts under incomplete information is higher than that under complete information.

Now consider the case of strong civil liberties protection. Here, the presence of informational asymmetry increases the incidence of illegitimate witch-hunts from zero to $\rho \alpha^{*}\left(1-\beta^{*} p\right)$, but decreases the incidence of tolerable witch-hunts by $(1-\rho) \beta^{*} p$ (from $(1-\rho)$ to $\left.(1-\rho)\left(1-\beta^{*} p\right)\right)$. The first effect is caused by the fact that the leader can manipulate his informational advantage to launch an illegitimate witch-hunt. The second effect reflects the fact that a tolerable witch-hunt can be stopped by the citizen's resistance under incomplete information. If the second effect is larger than the first effect, that is, if $(1-\rho) \beta^{*} p>\rho \alpha^{*}\left(1-\beta^{*} p\right)$, then the presence of informational asymmetry can actually reduce the overall incidence of witch-hunts. A decrease in $d$ increases the citizen's incentives to resist a witch-hunt, and therefore will reduce the leader's ability to manipulate his informational advantage to launch an illegitimate witch-hunt but will not decrease the probability of a citizen resisting a tolerable witch-hunt. This suggests that 
when $d$ is sufficiently small, the presence of informational asymmetry can reduce the overall incidence of witch-hunts.

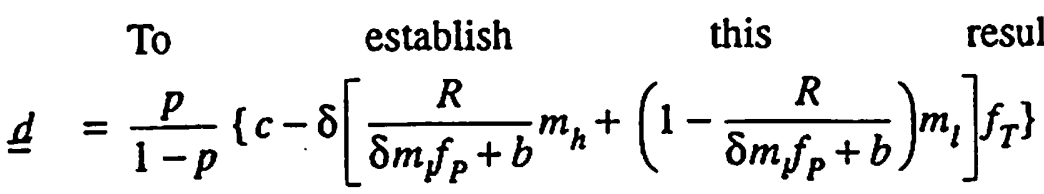

$\underline{d}=\frac{p}{1-p}\left\{c-\delta\left[\frac{R}{\delta m_{f_{P}}+b} m_{h}+\left(1-\frac{R}{\delta m_{l} f_{P}+b}\right) m_{l}\right] f_{T}\right\}$. By calculation, it can be shown that the necessary and sufficient condition for $(1-\rho) \beta^{*} p>\rho \alpha^{*}\left(1-\beta^{*} p\right)$ is that $d<\underline{d}$. This in turn requires that $\underline{\underline{d}}>0$. Note that so long as $c>\delta\left[\frac{R}{\delta m_{f_{P}}+b} m_{h}+\left(1-\frac{R}{\delta m_{f_{P}}+b}\right) m_{l}\right] f_{T}$, then $\underline{d}>0$ and moreover, $\underline{d}<\underline{d}$. Note that the L.H.S. of this necessary and sufficient condition for $\underline{d}>0$ is the cost imposed on the citizen by a witch-hunt, and the R.H.S. is a weighted average of the benefit of a witch-hunt to the citizen, where the "weight" is the leader's reputational loss-benefit ratio for launching an illegitimate witch-hunt. When this condition holds, so long as $d$ is smaller than the threshold value $\underline{d}$, or equivalently, so long as the level of civil liberties protection is larger than $\overline{\bar{l}}=d^{-1}(\underline{d})>i$, the overall incidence of witch-hunts under incomplete information will be lower than that under complete information. 6

Proposition 5. At any level of civil liberties protection, the presence of informational asymmetry always increases the incidence of illegitimate witch-hunts. However, when there is strong civil liberties protection, the presence of informational asymmetry reduces the incidence of tolerable witch-hunts. Therefore, when civil liberties protection is sufficiently strong, the overall incidence of witch-hunts under incomplete information is lower than that under complete information.

I now comment briefly on what happens if we relax assumptions A1-A3. Recall that Al says that $\rho>\frac{\delta m_{h} f_{T}-c}{\delta\left(m_{h}-m_{l}\right) f_{T}}$. If Al does not hold, when $\tilde{\rho}=\rho$, the citizen believes that there is a sufficiently large probability that the menace is high and she will not resist a witch-hunt even when it is costless to do so. Therefore, for any level of $l$, the only equilibrium is the pooling equilibrium $(L, L, N E)$. Suppose that $\mathrm{A} 2$ does not hold so that $\delta m f_{P}+b<R$. In this case, the leader's reputation loss for launching an illegitimate witch-hunt is greater than his benefits. The low type leader's dominant strategy will thus be "not launch" and the equilibrium will now be the sep- 
arating equilibrium ( $L, N L, N E$ ) for every level of civil liberties protection. If A3 does not hold, that is, when $p \leq 1-\frac{R}{\delta m_{1} f_{p}+b-F}$, then even if the low type leader anticipates that the citizen will resist the witch-hunt, he will still launch an illegitimate witch-hunt. The equilibrium will be $(L, L, N E)$ and $(L, L, E)$ when $l \leq i$ and $l>i$, respectively.

\section{Discussion}

Massive purges like the European Witch-hunts, the Anti-Communist Purge, and the Chinese Cultural Revolution are extremely complex phenomena. Despite this complexity, and the fact that these purges occurred in very different historical and institutional settings, many scholars have expressed the belief that there are important similarities between these events. This suggests the need to investigate to what extent there are fundamental dimensions common to these purges. If we can identify such dimensions, then we can develop analytical frameworks to clarify mechanisms through which differences in institutions and historical factors interact to affect the course of events in these purges. This paper represents a modest, but I hope useful, first step toward such a theory of witch-hunts. The framework and results reported here also generate a number of additional insights that can help us identify other aspects of these under-explored events. I conclude the paper with an discussion of these ideas, questions, and directions for future research.

In the current paper, civil liberties protection was modeled as a single exogenous parameter. However, differences in formal and informal institutions--for example, a nation's constitution and its civic traditions--play important roles in determining the effective level of civil liberties protection and the cost of resistance. For example, given that the judiciary plays an important role in determining the level of civil liberties protection, future research should investigate how differences in the de facto constitutional relationships between the executive, the legislature, and the judiciary affect the course of events in witch-hunts. For example, as Hamilton and Madison have eloguently argued in the Federalist papers (e.g., Nos. 10, 51, and 78), separation of powers between the three branches of government is extremely important for civil liberties protection. Future research should investigate how the degree of influence by the legislature and the executive 
over the selection and removal of judges, and the extent to which the judiciary has the right to judicial review, determine the effective level of civil liberties protection, and hence affects the incidence of witch-hunts.

Future research should also investigate the importance of informal social norms and traditions in witch-hunts. For example, the extent to which there has been a long history of open discussion and recognition of the importance of freedom of expression and dissent may affect the cost of resistance. As Kuran $(1987 ; 1995)$ has demonstrated, besides overt political coercion, subtle social pressure can also often cause people to falsify their preferences even in democratic societies. The current analysis highlights the importance of information asymmetries and the citizen's cost of resistance as crucial in determining the incidence of witch-hunts. With further development, this perspective may enable us to better understand the extent to which the strength of civic traditions (Putnam, 1993; also see Coleman, 1990) can affect the incidence of witch-hunts through its effect on the citizen's cost of resistance.

For example, suppose a citizen believes that in an on-going witch-hunt, the government is adopting processes that are unjustified, and she also expresses her criticisms publicly. Confronted with such criticism, other citizens have to decide whether this critic is an "innocent" person who has a genuine concern for due process, or whether she is simply a "witch" who is attempting to stop the witch-hunt with her criticism. ${ }^{7}$ A lack of civic traditions implies that people are not accustomed to the idea that people can have a strong respect for civil liberties and are even willing to incur personal risk to ensure that society upholds this ideal. In the limit, if other citizens do not have the idea that "concerned citizens" exist, then any citizen who criticizes a witch-hunt on the ground that it violates generally-practiced laws will automatically be classified as a witch. The model presented here suggests that the weaker the civic traditions in society, the higher the incidence of witch-hunts, since a potential critic is more likely to suffer as a result of his criticism against the witch-hunt due to the existence of the informational problem.

This implication can be seen from a slightly different perspective. Suppose that a society has a well-established civic tradition so that people are accustomed to observing that some citi- 
zens voice their concerns for civil liberties in public life--which can take the form of objections to certain actions by the government or other citizens on the grounds that they violate the civil liberties of others. If there has been a long history of open discussion regarding the importance of civil liberties, certain citizens who have a reputation for having a strong concem for civil liberties will emerge as credible social leaders. If a witch-hunt occurs, they are less likely to suffer from the "informational danger" faced by a critic. While their decisions regarding whether to speak out will of course depend on many other considerations, their existence increases the probability that successful countervailing actions against a witch-hunt can be organized. This will reduce the leader's incentives to launch a witch-hunt.

Another important extension of the current analysis is to take into account the "collective action" aspects of witch-hunts. The fact that an individual's decision conceming whether to participate in political resistance and similar kinds of collective actions depends on her expectation about how likely others are going to do so has long been emphasized by scholars (Olson, 1965; Tullock, 1971; Schelling, 1978). Some recent examples include Kuran's (1995) work on preference falsification and revolution (Kuran, 1995) and Weingast's (1995) work on federalism. Kuran emphasizes that when deciding whether to reveal their true preferences toward the current political regime, a citizen will take into account how likely it is that others will do so as well. Weingast studies how coordination problems between citizens can prevent them from resisting state transgressions against their political and economic rights. In these studies, however, a citizen knows whether a particular policy or the political status quo is desirable from his perspective. My analysis here highlights a situation in which a citizen may not even have enough information to determine whether a particular policy--i.e., the launch of a witch-hunt--is desirable from his own standpoint. The representative citizen model in this paper abstracts from interactions between citizens in witch-hunts, in order to better focus on how the presence of this information problem and differences in the level of civil liberties protection jointly determine the incidence of witch-hunts.

An earlier and much longer draft of this paper contains an extension of the current model to take into account some collective action aspects of witch-hunts. In this extended model, the 
leader decides whether to launch a witch-hunt after he observes the level of menace, and two citizens then simultaneously decide whether to resist it without observing the realized level of menace. The model emphasizes both the strategic complementarity between the citizens' countervailing actions--that is, countervailing actions undertaken by one citizen increases the effectiveness of countervailing actions undertaken by the other, and vice versa--and the fact that each citizen has the incentive to free-ride on the other's resistance.

Incorporating these considerations generates some interesting insights regarding how differences in institutions shape the interactions between the citizens. For example, under weak civil liberties protection, once the leader launches a witch-hunt, the subgame played by the two citizens resembles a prisoner's dilemma and no citizen will resist the witch-hunt in equilibrium. However, a sufficiently large improvement in civil liberties protection can transform this subgame into a game in which "cooperation" between the citizens can emerge in equilibrium. Importantly, it can be shown that qualitatively, the comparative static results reported here still hold even when we take into account the importance of free-riding and strategic complementarity. With simplification, the reason is as follows. As should be clear from the analysis above, our conclusions regarding how informational asymmetry and civil liberties protection jointly affect the equilibrium incidence of witch-hunts are driven by the fact that the probability that the citizen will resist a witch-hunt is increasing in both $\tilde{\rho}$ (the citizen's posterior belief that a witch-hunt is illegitimate) and $l$, and these monotonicity properties still hold in a multiple citizen setting.

The paper emphasizes the importance of the leader's informational advantage over the citizen about the level of menace in determining the incidence of witch-hunts. Future research should study how, more generally, differences in the nature of information flows within a society affect the dynamics of witch-hunts. A reading of historical accounts about McCarthyism suggests that while informational asymmetry was important in shaping the development of the purges, in comparison to the case of the Cultural Revolution, people were much better-informed about some key developments that affected the payoffs of different courses of action available to them. Due to the work of the media, people in different communities--including the local political elites, opin- 
ion leaders, and the public--had access to information about the purges of high-profile national figures, as well as "local" purges in other communities. Moreover, in choosing their future actions, politicians were aided by the fact that they had access to some useful, though imperfect, measures--like polls--of how people reacted to their earlier actions and those of their colleagues.

In contrast, during the Cultural Revolution, both the populace and local political leaders were much less well-informed about the developments in other communities and at higher levels of the political hierarchy. Compared to their U.S. counterparts, senior political leaders--including Mao himself-had less reliable channels for discerning people's reactions to their policies. This is in part due to the fact that given the nature of the political system, their subordinates had especially strong incentives to distort relevant information to their advantage (Walder, 1994). Future research should investigate how differences in the nature of information flow and political institutions determine who will accuse whom when, the timing of countervailing actions, and when political leaders will engage in actions to prevent citizens' from resisting. ${ }^{8}$

Finally, an important fact about witch-hunts is their recurrence, especially the fact that "similar" tragedies can recur in the same community within a short period. For example, while there was some reflection on the excessiveness of the Red Scare in the post-WWI period, this did not prevent similar events from happening again in the U. S. about three decades later. This observation suggests the need to study the legacies of witch-hunts. In particular, under what conditions will the occurrence of a witch-hunt, which was eventually perceived to be illegitimate by contemporary observers, spark off effective changes in institutions and people's beliefs so that it will enable society to better prevent similar tragedies in the future? Also, under what conditions will the victims, the witch-hunters, and the close observers of a witch-hunt engage in sincere private soul-searching on the causes and legacies of the tragedy? When will some of them publicly debate possible institutional reforms to prevent these tragedies? When will political elites, academic leaders, and other opinion leaders have incentives to manipulate, or even suppress such discussion? A better understanding of these important issues will enable us to better understand how to design institutions or foster civic traditions to better prevent the occurrence of tragic witch-hunts. 


\section{Footnotes}

*I am grateful to George Akerlof, Serguey Braguinsky, John Elliott, Duncan Foley, David Friedman, Nuno Garoupa, Ruth Given, Laurence Iannaccone, Kai Konrad, Timur Kuran, Julia Liebeskind, John Matsusaka, Shailendra Mehta, Evan Osbome, James Robinson, Pablo Spiller, Ivo Welch, Oliver Williamson, Ulrich Witt, seminar participants at USC, California State University at Fullerton, the 1998 annual meetings of the American Economic Association and the Public Choice Society, and especially Nick Argyres and two anonymous referees, for helpful comments and discussions. I have also benefitted from extended conversations with Matthew Rabin about witch-hunts and related issues.

1. A notable exception is Oplinger (1990). Building on the sociological literature on deviance (Currie, 1968; Ben-Yehuda, 1985), he argues that the European Witch-Hunt, McCarthyism, and other massive purges are all incidence in which the social control system of the state is used by powerful elites to identify and punish deviant behavior on a massive scale. He also argues that the less a social control system is subject to accountability and organizational restraint, the greater the potential for deviance production. Oplinger (1990), however, does not identify the dimensions of institutions along which societies differ in terms of "accountability and restraint," nor does he characterize the mechanisms by which such differences affect the incidence of witch-hunts.

2. Conducting a witch-hunt can also divert the leader's attention and resources from other important issues that he either cares about genuinely; or the neglect of which will reduce the political supports he receives. Oshinsky (1983) reports that even when McCarthy's anti-communist campaign enjoyed strong support, many powerful interest groups in Wisconsin (e.g. diary farmers) were concerned that he had become a "single issue" senator and was not paying enough attention to their other interests. My formulation can easily take these costs into account if we think of $b$ as the leader's net instrumental benefits from conducting the witch-hunt. 
3. Formally, $\bar{\rho} \equiv \operatorname{Prob}$ ( $P$ is a low type leader a witch-hunt is launched), which in tum equals $\frac{\operatorname{Prob}(P \text { is a low type leader, a witch-hunt is launched })}{\operatorname{Prob}(A \text { witch-hunt is launched })}=\frac{\rho \alpha^{*}}{\rho \alpha^{*}+(1-\rho)}$.

4. Note that $\tilde{\rho}=\frac{\rho \alpha^{*}}{\rho \alpha^{*}+(1-\rho)}$ implies that $\frac{\partial \tilde{\rho}}{\partial \alpha^{*}}>0$. This reflects the fact that the lower the probability that the low type leader will launch a witch-hunt, the larger the citizen's "downward" adjustment in her posterior belief.

5. I am grateful to an anonymous referee for inspiring comments on this issue.

6. This result can be interpreted as saying that while an increase in civil liberties protection reduces the probability of type I error, it increases the probability of type II error in equilibrium, and it is possible that the second effect can dominate the first. Therefore, while the exact value of the threshold $\underline{d}$, as well as how it varies with the parameters of the model, of course depends sensitively on the details of the model, I believe that the qualitative result that informational asymmetry can actually reduce the overall incidence of witch-hunts is robust.

7. See Loury (1993) for a model of "political correctness" that shows how this kind of informational problem can cause a person to engage in self-censorship. Also see Posner (1998) on how state interventions--for example, the passage of an anti-flag-buming law or an anti-discrimination law--can either magnify or mitigate this kind of informational problem and hence affects the incidence of self-censorship.

8. Besides strategic considerations, psychological factors may also affect the timing of countervailing actions. For example, Akerlof (1991) has argued that in making decisions, individuals tend to assign undue weight to current costs relative to more distant costs, and demonstrates that this mechanism may be important in explaining why people failed to resist Stalin's ascent to power. 


\section{References}

Akerlof, George. 1991. "Procastination and Obedience," 81 American Economic Review 1-19.

Barnouin, Barbara, and Changgen Yu. 1992. Ten Years of Turbulence: The Chinese Cultural Revolution. New York: Kegan Paul Intemational.

Ben-Yehuda, Nachman. 1985. Deviance and Moral Boundaries. Chicago: University of Chicago Press.

Briggs, Robin. 1996. Witches and Neighbors: The Social and Cultural Context of European Witchcraft. New York: Penguin Books.

Caute, David. 1978. The Great Fear: The Anti-Communist Purge under Truman and Eisenhower. New York: Simon and Schuster.

Cohn, Norman. 1975. Europe's Inner Demons: An Inquiry Inspired bv the Great Witch-hunts. New York: New American Library.

Coleman, James. 1990. Eoundation of Social Theory. Cambridge: Harvard University Press.

Clark, Stuart. 1997. Thinking with Demons: The Idea of Witchcraft in Early Modem Europe. Oxford: Clarendon Press.

Currie, Elliot. 1968. "Crimes without Criminals: Witchcraft and its Control In Renaissance Europe," 3 Law and Society Review 7-32.

Dittmer, Lowell. 1987. China's Continuous Revolution: The Post-Liberation Epoch. 1949-1981. 
Berkeley, University of California Press.

Evans-Pritchard, E. E.. 1937. Witchcraft. Occult. and Magic among the Azande. Oxford: Clarendon Press.

Fried, Richard, M. 1990. Nightmare in Red: The McCarthy Era in Perspective. New York: Oxford University Press.

Goodman, Walter. 1964. The Committee: The Extraordinary Career of the House Committee on Un-American Activities. New York: Farrar, Straus \& Grioux.

Hall, David. 1985. "Witchcraft and the Limit of Interpretation," 59 New England Quarterly 253281.

Harding, Harry. 1993. "The Chinese States in Crisis," in R. MacFarquhar, ed., The Politics of China: 1949-1989. New York: Cambridge University Press.

Klaits, Joseph. 1985. Servants of Satan: The Age of the Witch Hunts. Bloomington: Indiana University Press.

Klingaman, William K. 1996. Encyclopedia of the McCarthy Era. New York: Facts on File, Inc.

Kuran, Timur. 1987 "Preference Falsification, Policy Continuity, and Collective Conservatism," 97 Economic Journal 642-665.

1995. Private Truths. Public Lies: The Social Consequences of Preference Falsification. Cambridge: Harvard University Press. 
Lamer, Christina. 1981. The Enemies of God: The Witch-hunt in Scotland, Baltimore: Johns Hopkins University Press.

Lee, Hong Yung. 1978. The Politics of the Chinese Cultural Revolution; A Case Study. Berkeley: University of California Press.

Levack, Brian. 1995. The Witch-hunt in Early Modern Europe. London: Longman.

Loury, Glenn. 1994. "Self Censorship in Public Discourse: A Theory of 'Political Correctness' and Related Phenomena," 6 Rationality and Society 428-461.

Midelfort, H.C. Erik. 1992. "Witch Hunting and the Domino Theory," in B. Levack, ed., WitchHunting in Early Modern Europe: General Studies. New York: Garland Publishing, Inc.

Olson, Mancur. 1965. The Logic of Collective Action. Cambridge: Harvard University Press.

Oplinger, Jon. 1990. The Politics of Demonology: The European Witchcraze and the Mass Production of Deviance. London: Associated University Press.

Oshinsky, David M. 1983. A Conspiracy So Immense: The World of Joseph McCarthy. New York: The Free Press.

Posner, Eric A. 1998. "Symbols, Signal, and Social Norms in Politics and the Law," forthcoming, Journal of Legal Studies.

Putnam, Robert. 1993. Making Democracy work: Civic Traditions in Modern Italy. Princeton: 
Princeton University Press.

Reeves, Thomas C. 1982. The Life and Times of Joe McCarthy. New York: Stein and Day.

Rovere, Richard H. 1959. Senator Joseph McCarthy. New York: Harcourt \& Bruce.

Schelling, Thomas. 1978. Micromotives and Macrobehavior. New York: W. W. Norton.

Thomas, Keith. 1971. Religion and the Decline of Magic. New York: Charles Scribner's Sons.

Tullock, Gordon. 1971. "The Paradox of Revolution," 11 Public Choice 89-99.

Walder, Andrew G. 1994. "Collective Behavior Revisited: Ideology and Politics in the Chinese Cultural Revolution," 6 Rationality and Society 400-421.

Weingast, Barry. 1995. “The Economics Role of Political Institutions: Market Preserving Federalism and Economic Development,"11 Loumal of Law. Economics, \& Organization 1-31.

Whyte, Lynn T. III. 1989. Policies of Chaos: The Organizational Causes of Violence in China's Cultural Revolution. Princeton: Princeton University Press.

Yan, Jiaqi, and Gao Gao. 1986. Zhongguo "Wenge" Shinan Shi (A History of the Decade of China's "Cultural Revolution"), Hong Kong: Dagongbao Press.

Yue, Daiyun and Carolyn Wakeman. 1986. To the Storm: The Odyssey of a Revolutionary Chinese Woman. Berkeley: University of Califomia Press. 


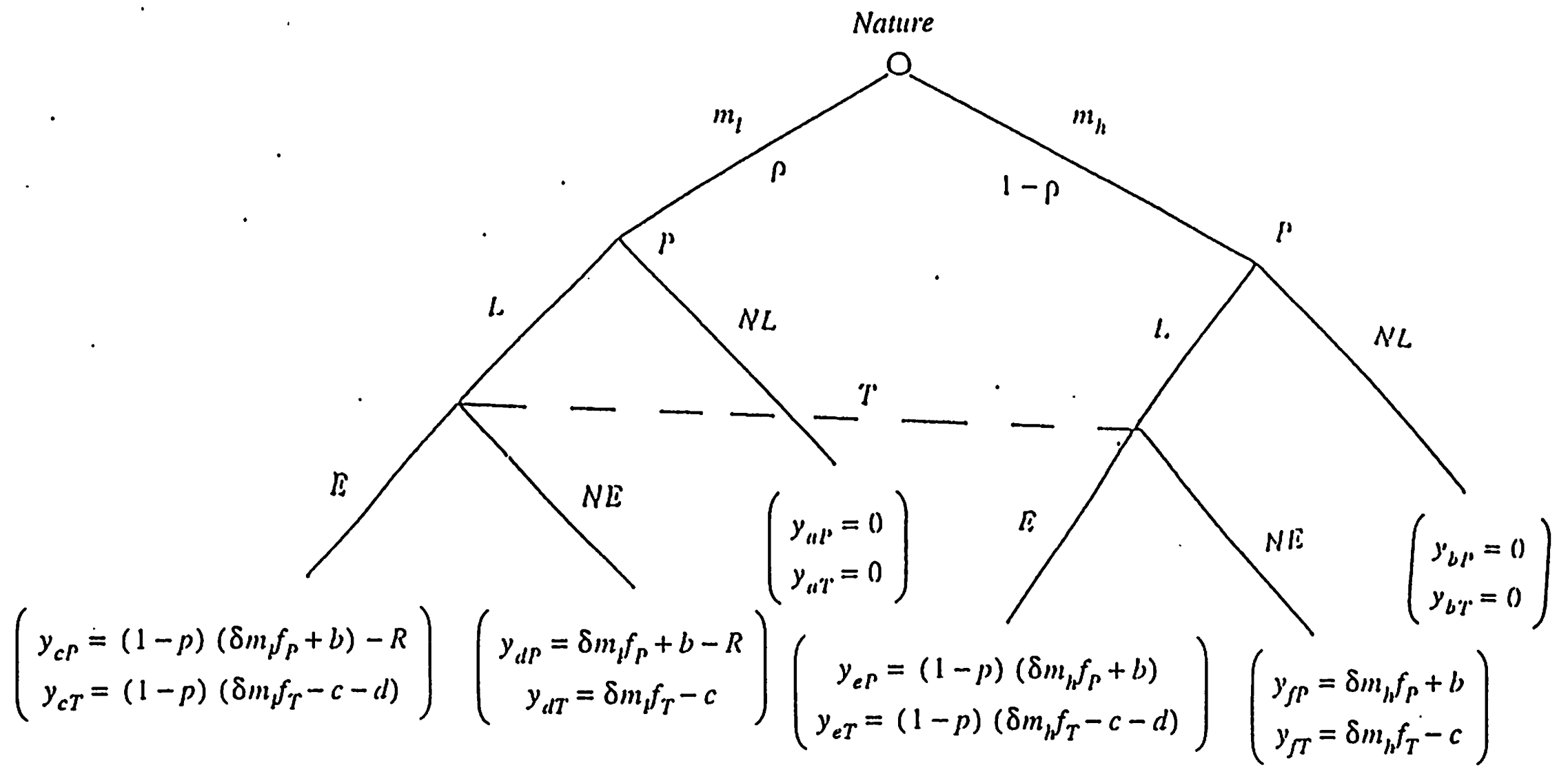

Figure 1 
Table 1

E(yuilibrium strategies of the players and the equilibrium incidence of witch-hunts as a function of (i) the level of civil liberties protection and (ii) whether there is complete or incomplete information

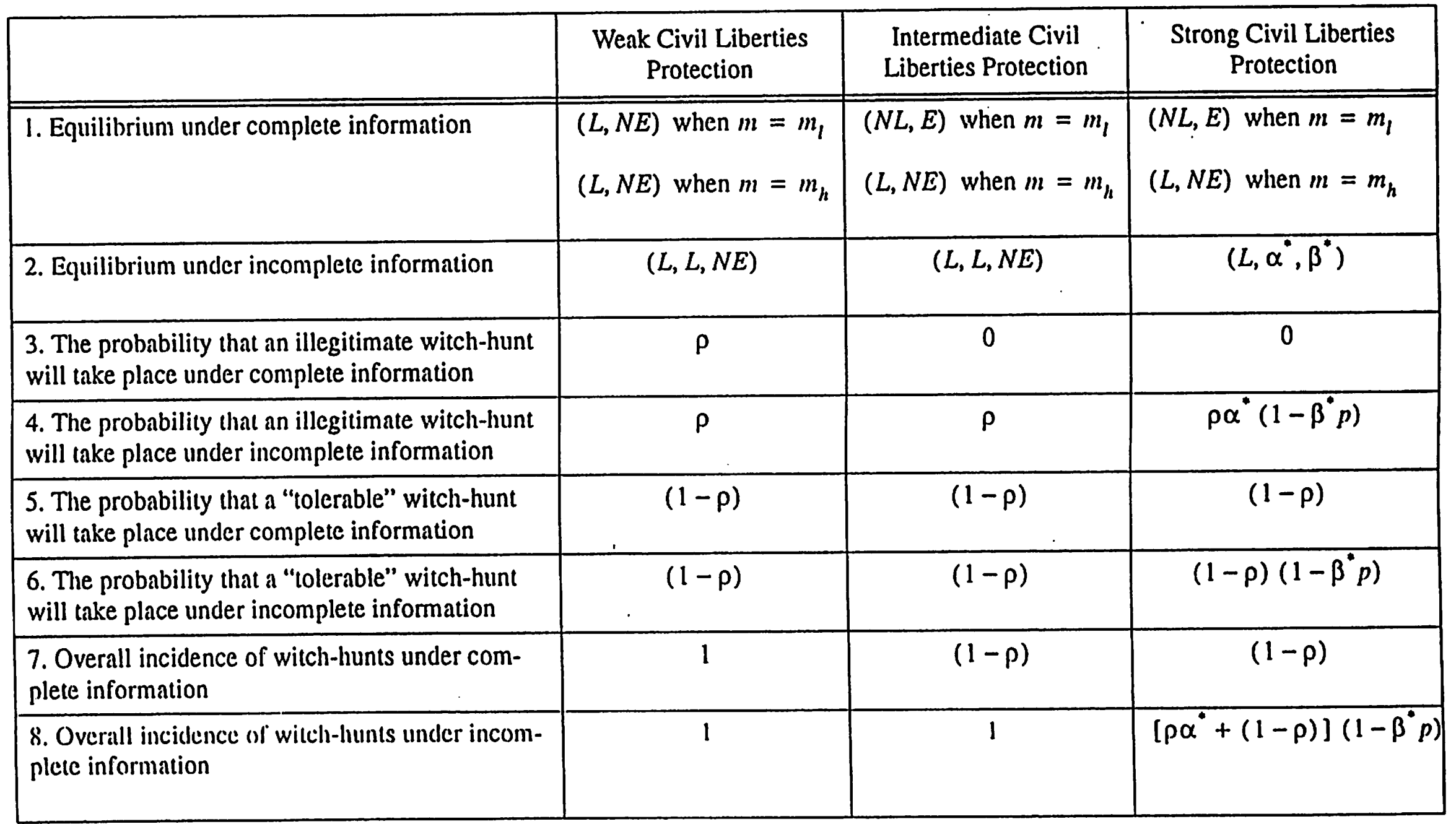

